\title{
Effect of the turbot aquareovirus on fish macrophages using an in vitro model
}

\author{
Carmen Rivas ${ }^{1}$, Isabel Bandín ${ }^{1}$, Manuel Noya ${ }^{2}$, Carlos P. Dopazo ${ }^{1, *}$, \\ Catalina Cepeda ${ }^{1}$, Juan L. Barja ${ }^{1}$
}

${ }^{1}$ Departamento de Microbiología y Parasitología, ${ }^{2}$ Departamento de Biología Fundamental, Facultad de Biología, Universidad de Santiago de Compostela, E-15706 Santiago de Compostela, Spain

\begin{abstract}
The turbot aquareovirus TRV has an invasive behaviour, as the virus spreads throughout most fish organs and tissues. In the present study the presence of TRV inside macrophages of both naturally and experimentally infected turbot was demonstrated, and the ability of the virus to resist killing and to replicate within turbot macrophages in vitro was evaluated. The virus survived and replicated in the phagocytic cells, as demonstrated by electron microscopy and growth curve. Superoxide anion $\left(\mathrm{O}_{2}{ }^{-}\right)$production of phorbol 12-myristate 13-acetate (PMA)-stimulated macrophages infected with TRV was similar to that of normal macrophages. However, the levels of $\mathrm{O}_{2}^{-}$produced by macrophages infected with a non-virulent Aeromonas salmonicida strain lacking the A-layer were clearly reduced when phagocytic cells had been previously incubated with TRV, but this reduction did not modified the ability of infected macrophages to kill the bacteria. These results indicate that the viral agent eludes the recognition system of the macrophages and the bactericidal capacity of these phagocytic cells is not affected by the presence of the virus, although the interaction with the virus must affect the mechanism of reduction of molecular oxygen into $\mathrm{O}_{2}$
\end{abstract}

KEY WORDS: Aquareovirus Turbot macrophages $\cdot$ Killing $\cdot$ Survival

\section{INTRODUCTION}

In fish, as in other vertebrates, phagocytes are a major defense against infection (Avtalion \& Shahrabani 1975, MacArthur \& Fletcher 1985, Olivier et al. 1986). In fact, it has been demonstrated that pathogenic organisms and particulate antigens are rapidly removed from the blood by tissue-fixed macrophages (Rubin et al. 1987).

Macrophages play an essential role in resistance to viral infections (Mogensen 1979, Haller 1981, Mogensen \& Virelizier 1987). They can restrict viral replication by inactivation of extracellular viruses, lysis of virus-infected cells, secretion of enzymes competing for virus-dependent substrates, or production of defective interfering virus (Morahan et al. 1985). Nevertheless, a variety of viral pathogens have chosen pre-

\footnotetext{
•Addressee for correspondence. E-mail:mpdopazo@usc.es
}

cisely this type of cell as their preferred habitat (Burstin et al. 1983, Stoddart \& Scott 1989). In this sense, several studies have demonstrated the important role of macrophages in the infectivity of reoviruses (Papadimetriou 1965, 1968).

Our previous studies involving in vitro infection of turbot tissues with the turbot aquareovirus TRV have shown that this virus replicates mainly in the kidney, but also, to a lesser extent, in the liver and heart. In addition, infection trials indicated that this viral agent spreads quickly within the organism, maintaining relatively high viral titers in most fish tissues and finally developing a persistent infection in the host. One possible route for the rapid dissemination of the virus throughout all fish organs and tissues could be the circulatory system. However, no virus was detected in the serum nor in red cells from either naturally or experimentally infected turbot (Rivas et al. 1993, in press).

Therefore, we decided to investigate the role of macrophages in TRV infection. The interaction be- 
tween the viral agent and fish macrophages could be of crucial importance in explaining some aspects of the TRV invasion process, including penetration into the host and infection of target tissues

In the present study, the presence of TRV within macrophages from naturally and experimentally infected turbot was assessed and the capacity of the virus to enter macrophages and to replicate within them was evaluated using an in vitro model. Moreover, the effect of the virus on superoxide anion production, an important defence mechanism in macrophages (Secombes \& Fletcher 1992), was also tested

\section{MATERIALS AND METHODS}

Isolation of resident trout and turbot macrophages. Macrophages were obtained from the head kidney of turbot Scophthaimus maximus basicaily as previously described (Graham \& Secombes 1988). Briefly, the head kidney was aseptically removed and disrupted through a $100 \mu \mathrm{m}$ nylon mesh, with $5 \mathrm{ml}$ Leibovitz' medium (L-15) containing $2 \%$ foetal calf serum (FCS), penicillin (100 $\left.\mathrm{IU} \mathrm{ml}^{-1}\right)$, streptomycin $\left(100 \mu \mathrm{g} \mathrm{ml}^{-1}\right)$ and $10 \mathrm{IU} \mathrm{ml^{-1 }}$ heparin. The cell suspension was layered onto a 34 to $51 \%$ Percoll (Sigma) discontinuous density gradient and centrifuged at $400 \times g$ for $30 \mathrm{~min}$ at $4^{\circ} \mathrm{C}$ Cells separated in the interface were collected, centrifuged at $400 \times g$ for $5 \mathrm{~min}$ and resuspended in L-15 supplemented with $1 \%$ FCS. Viable cell concentration was determined by trypan blue exclusion, and $2 \times$ $10^{7}$ cells $\mathrm{ml}^{-1}$ were allowed to adhere to 24 - or 96-well plates. After $3 \mathrm{~h}$ at $15^{\circ} \mathrm{C}$, unattached cells were discarded and the remaining adhering cells on the plates were covered with L-15 supplemented with $5 \%$ FCS. About $95 \%$ or greater of these cells were macrophages as judged by morphology.

Virus and cells. The aquareovirus TRV isolated in the northwest of Spain from turbot suffering from a mixed bacterial and viral infection (Lupiani et al. 1989) was used in this study. The virus was propagated in monolayers of chinook salmon embryo cells (CHSE214) at $15^{\circ} \mathrm{C}$, by inoculation at a multiplicity of infection (MOI) of 0.1. Eagle's Minimal Essential Medium (EMEM) supplemented with $2 \%$ FCS, $100 \mathrm{IU} \mathrm{ml}^{-1}$ penicillin and $100 \mu \mathrm{g} \mathrm{ml}^{-1}$ streptomycin was used. When the cytopathic effect was extensive, the cells were scraped of and subjected to freezing-thawing. The suspensions were clarified by low-speed centrifugation $\left(2000 \times g\right.$ for $10 \mathrm{~min}$ at $\left.4^{\circ} \mathrm{C}\right)$ and stored at $-80^{\circ} \mathrm{C}$ until use.

All virus infectivity assays were carried out as triplicate microtitrations on CHSE-214 cells in 96-well culture plates. Results were recorded after $14 \mathrm{~d}$ incubation at $15^{\circ} \mathrm{C}$, and $50 \%$ infectivity end-points calculated according to Reed \& Müench (1938), and expressed as average $\mathrm{TCID}_{50} \mathrm{ml}^{-1}$.

Bacterial strains. Aeromonas salmonicida strain MT004 (Marine Laboratory, Aberdeen, Scotland), a non-virulent strain lacking the A-layer and susceptible to killing by normal trout macrophages (Graham et al. 1988 ), was cultured in tryptic soy broth (TSB) for $24 \mathrm{~h}$ at $22^{\circ} \mathrm{C}$

Detection of TRV in macrophages from naturally and experimentally infected turbot. A group of 5 turbot averaging $1 \mathrm{~kg}$ were intraperitoneally injected with $1 \mathrm{ml}$ of TRV $\left(10^{5} \mathrm{TCID}_{50} \mathrm{ml}^{-1}\right)$. A second group of 5 fish were injected with $1 \mathrm{ml}$ of EMEM and used as controls. Fish were held in $20 \mathrm{l}$ aquaria at $15^{\circ} \mathrm{C}$ with aeration. After $2 \mathrm{~d}$ the macrophages were isolated as described above, diluted to a concentration of $2 \times 10^{7}$ cells $\mathrm{mil}^{-1}$, lysed by freezing-thawing, and intracellular virus titrated as described above.

In addition, macrophages isolated from turbot obtained from a fish farm known to have TRV carrier fish were processed in the same way.

Electron microscopy. Macrophage monolayers on plastic coverslips in 24-well tissue culture plates were inoculated with TRV at a MOI of 10 . After a $1 \mathrm{~h}$ adsorption, monolayers were washed 3 times with phosphate buffered saline (PBS) covered with $200 \mu \mathrm{l}$ of EMEM containing penicillin and streptomycin, and incubated at $15^{\circ} \mathrm{C}$. At different times post-infection, coverslips were removed, washed, and infected cells fixed with $2.5 \%$ glutaraldehyde in cacodylate buffer $(0.1 \mathrm{M}, \mathrm{pH} 7.4)$ for $1 \mathrm{~h}$ at $4^{\circ} \mathrm{C}$. Cells were scraped off, washed, and rinsed overnight at $4^{\circ} \mathrm{C}$ in the same buffer. Post-fixation was performed in $2 \%$ osmium tetroxide for $1 \mathrm{~h}$. Cells were then dehydrated and embedded in Epon. Serial ultrathin sections were collected on 150-mesh grids, counterstained with uranyl acetate and lead citrate and then observed on a Philips CM-12 electron microscope.

Viral invasion and intracellular survival assays. Monolayers of untreated and cytochalasin-D (a potent inhibitor of actin-dependent phagocytosis) treated (0.5 $\mathrm{\mu g} \mathrm{ml}^{-1}, 1 \mathrm{~h}$ before infection) macrophages, in 24 well tissue culture plates, were inoculated with viral suspensions at a MOI of 10 . After $1 \mathrm{~h}$ of adsorption at $4^{\circ} \mathrm{C}$, infected cells were washed 3 times with PBS and covered with $200 \mu$ l of EMEM containing penicillin and streptomycin. Infected monolayers were incubated at $15^{\circ} \mathrm{C}$, and at different times the supernatant was completely recovered and titrated to determine viable extracellular viruses. The monolayers were washed 3 times with EMEM, and macrophages resuspended in $1 \mathrm{ml}$ of distilled water and lysed by 3 freezing-thawing cycles. After low-speed centrifugation, the supernatant was titrated to determine viable intracellular virus. The course of the infection was followed over a maximum 
period of 24 h. Simultaneously, macrophages infected with different MOI (0.1 to 10$)$ were observed at different times to follow the appearance of cytopathic effects.

Superoxide anion detection. For the detection of superoxide anion a method based on the reduction of Nitroblue tetrazolium (NBT, Sigma) was employed (Rook et al. 1985). This study was carried out using (1) uninfected macrophages; (2) macrophages infected with TRV for 5 and $30 \mathrm{~min}, 1,5,7$ and $24 \mathrm{~h}$, and $7 \mathrm{~d}$; (3) macrophages infected with TRV for 5 and $30 \mathrm{~min}$, and $5 \mathrm{~h}$, and then infected with $20 \mu \mathrm{l}$ of Aeromonas salmonicida $\left(2.4 \times 10^{9}\right.$ cells $\left.\mathrm{ml}^{-1}\right)$, and (4) macrophages infected only with $20 \mu$ of $A$. salmonicida. Thirty minutes after the infection macrophages were washed 3 times with phenol red-free Hanks' balanced salt solution (HBSS). The macrophage monolayers were then incubated at room temperature for $30 \mathrm{~min}$ in medium containing $1 \mathrm{mg} \mathrm{ml}^{-1} \mathrm{NBT}$ in the presence or absence of $100 \mathrm{ng} \mathrm{m}^{-1}$ of phorbol 12-myristate 13-acetate (PMA, Sigma), an activating agent of the respiratory burst. The optical density (OD) was read after $15 \mathrm{~min}$ in a multiscan spectrophotometer (Titertek Multiskan Plus, Flow) at $600 \mathrm{~nm}$. Assays were performed in quadruplicate for each of 3 individual fish. These data were analysed by Student $t$-test and 1 -way analysis of variance (ANOVA).

Bactericidal activity of TRV-infected macrophages against Aeromonas salmonicida. The assay was performed essentially as previously described (Graham et al. 1988). Monolayers of macrophages, in 96-well plates, were inoculated with TRV $\left(10^{5} \mathrm{TCID}_{50}\right.$ well $\left.^{-1}\right)$, and incubated at $15^{\circ} \mathrm{C}$. At different times $(5,30 \mathrm{~min} ; 4$. $19 \mathrm{~h}$ ), half of the monolayers on each plate were inoculated with different dilutions of $A$. salmonicida MT004 in TSB (from $2.5 \times 10^{7}$ to $9.6 \times 10^{4}$ cells $\mathrm{ml}^{-1}$ ), centrifuged and incubated for $5 \mathrm{~h}$ at $15^{\circ} \mathrm{C}$. The supernatant fluids were removed and all the monolayers lysed with $50 \mu$ l of $0.2 \%$ Tween 20 (Sigma). At this point, those wells which had not been infected with bacteria were inoculated with $A$. salmonicida, representing the 'zero time bactericidal determination'. Then, $100 \mu$ of TSB was added to each well to support an overnight growth at $18^{\circ} \mathrm{C}$ of the surviving bacteria. After this time, $10 \mu \mathrm{l}$ of 3-(4,5-dimethylthiazol-2-yl)2,5-diphenyltetrazolium bromide (MTT, Sigma) (5 mg $\mathrm{ml}^{-1}$ ) was added per well, and after exactly $15 \mathrm{~min}$ the optical density was read at $600 \mathrm{~nm}$ in a multiscan spectrophotometer (Flow). A bactericidal assay with uninfected macrophages was performed in parallel for comparative purposes. Assays were performed in quadruplicate and repeated 3 times. These data were statistically examined by a 2 -tailed Student $t$-test at a $5 \%$ level of significance.

\section{RESULTS}

\section{Detection of TRV in macrophages obtained from infected fish}

The presence of TRV within turbot macrophages was assessed in both naturally and experimentally infected turbot. Virus isolated after $2 \mathrm{~d}$ of the experimental fish infection showed titers between $10^{3}$ and $10^{4}$ TCID $_{50}$ per $2 \times 10^{7}$ phagocytic cells. The viral titer detected in phagocytic cells from naturally infected turbot at different times was slightly lower $\left(10^{2} \mathrm{TCID}_{50} \mathrm{ml}^{-1}\right)$.

\section{Electron microscopical examination of TRV-infected macrophages}

Electron microscopy was performed to verify the intracellular presence of TRV in fish macrophages during the infection assay. At different times post-infection (p.i.) cell structures associated with viral replication were observed inside infected macrophages. Fig. 1A shows the cytoplasm of TRV-infected phagocytic cells containing small viroplasmic areas, associated with rough endoplasmic reticulum (RER) cisternae, containing 45 to $50 \mathrm{~nm}$ subviral particles, which may represent partially formed virus. Incomplete viruses measuring from 25 to $45 \mathrm{~nm}$ were also observed scattered through the cytoplasm of infected cells (Fig. 1B).

\section{Entry of TRV into macrophages and intracellular growth}

The capacity of TRV to enter into macrophages and to grow intracellularly was evaluated by an in vitro model of infection over $24 \mathrm{~h}$, and the results are shown in Fig. 2. As observed, both intracellular (I.V.) and extracellular (E.V.) viruses were detected $2 \mathrm{~h}$ p.i. at relatively high levels (around $5 \times 10^{4} \mathrm{TCID}_{50} \mathrm{ml}^{-1}$ ). Titer of I.V. showed an exponential increase from 6 to $12 \mathrm{~h}$ p.i., reaching a maximum of $5.6 \times 10^{6}$ at $12 \mathrm{~h}$ p.i., which represents a total increase of 2 logs. Except for a small peak at $6 \mathrm{~h}$ p.i., the level of E.V. was relatively constant $\left(5 \times 10^{4} \mathrm{TCID}_{50} \mathrm{ml}^{-1}\right)$ throughout the experiment.

Development of syncytia is the typical cytopathic effect that aquareoviruses produce in continuous cell lines (Winton 1989). Although no syncytia appeared in TRV-infected macrophages, morphological changes in phagocytic cells were observed from the first hours post-infection (Fig. 3). However, changes in cell morphology were never followed by total destruction of the monolayers. Similar alterations were observed in macrophages previously incubated with cytochalasin-D. 


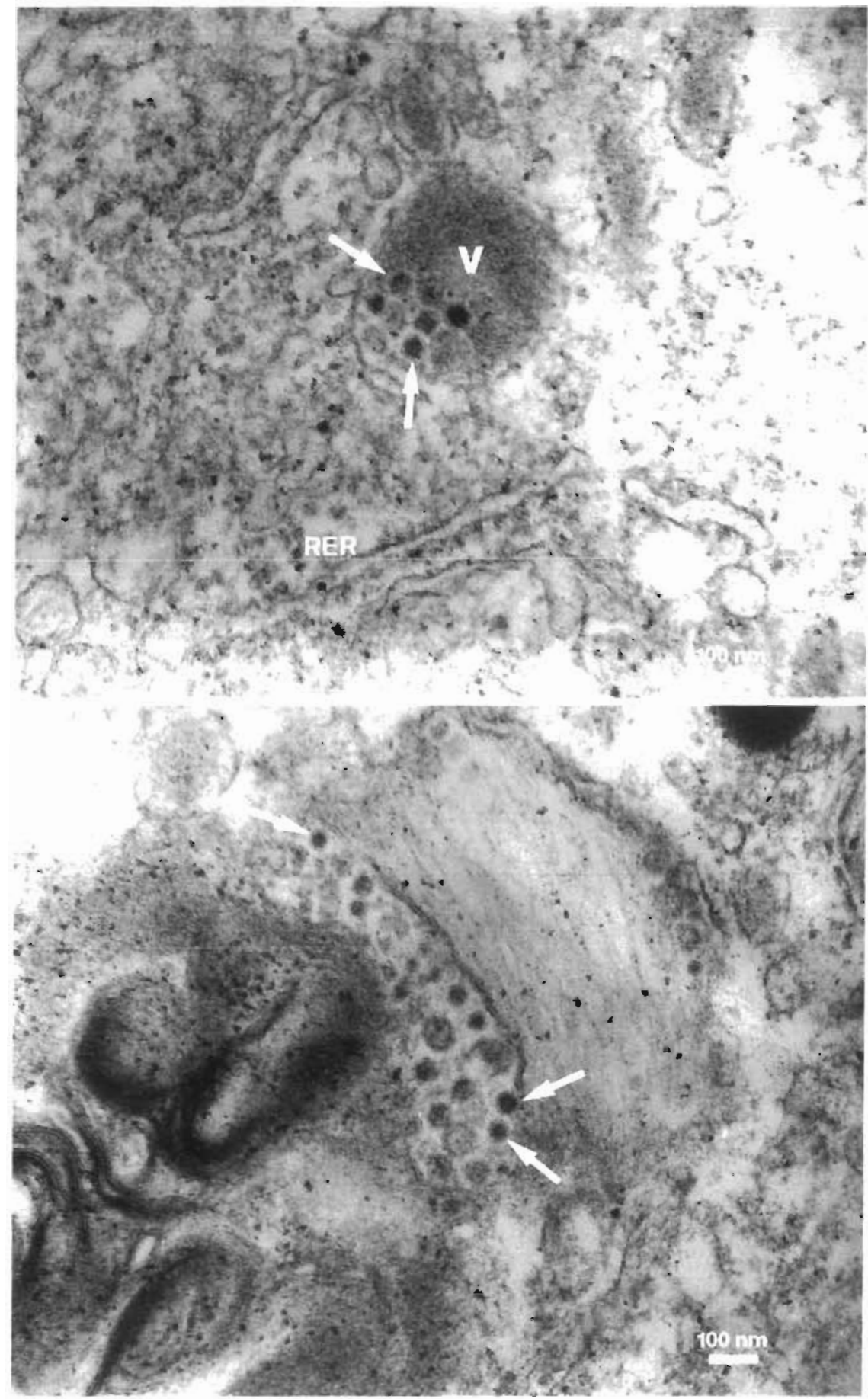

Fig. 1 Electron microscopy of turbot macrophages at $24 \mathrm{~h}$ after TRV infection. (A) A small area of viroplasm (V) which contains 45 to $50 \mathrm{~nm}$ virus particles (arrows) is located near vesicles of the RER. (B) Subviral structures 25 to $45 \mathrm{~nm}$ diameter (arrows) scattered through the cytoplasm of infected macrophages

\section{Superoxide anion detection}

This assay was performed in order to study the effect of TRV on the production of superoxide anion by PMAstimulated macrophages infected with TRV and/or Aeromonas salmonicida. No significant differences $(\mathrm{p}<0.05)$ in $\mathrm{O}_{2}^{-}$production were observed between non-infected macrophages and fish macrophages infected with TRV for different periods of time $15,30 \mathrm{~min}$; $\left.1,5,7,24 h_{i} 7 \mathrm{~d}\right)$, as shown in Fig 4A. However, incubation of phagocytic cells with TRV did reduce significantly $(p<0.05)$ the activation of the respiratory burst produced by the combination of PMA and A. salmonicida in macrophage monolayers (Fig. 4B). 


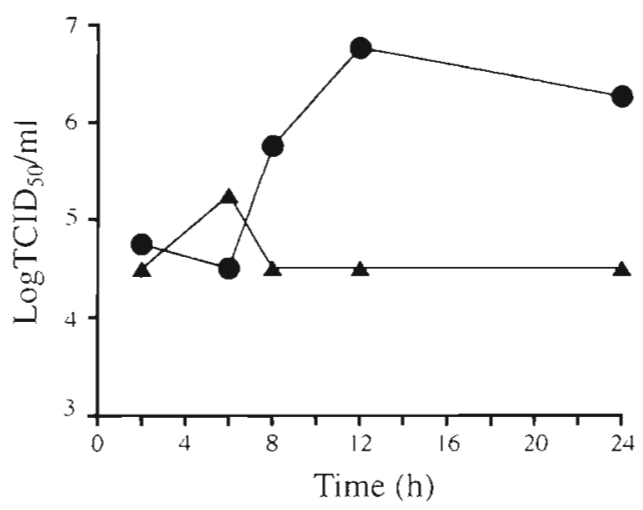

Fig. 2. Survival of TRV in turbot-derived macrophages cultures. Titer of viable extracellular virus $(\mathbf{\Delta})$; titer of viable intracellular virus (-)

\section{Bactericidal capacity}

In order to determine if the interaction between TRV and fish macrophages could affect the killing ability of phagocytic cells against another microorganism, a bactericidal assay against Aeromonas salmonicida was performed using macrophages previously incubated with TRV for 5 and 30 min, and for 4 and $19 \mathrm{~h}$. Our results showed that the capacity of TRV-infected macrophages to kill A. salmonicida (at a conc. of $2.5 \times 10^{7}$ cells $\mathrm{ml}^{-1}$ ) was virtually unaltered with respect to uninfected macrophages (Fig. 5). A. salmonicida was killed by both TRV-infected and uninfected macrophages after $5 \mathrm{~h}$ incubation, since a significant decrease $(p<0.05$, as determined by Student $t$-test) in the number of viable bacteria was

Fig. 3. Monolayers of TRV-infected and non-infected macrophages. (A) uninfected turbot-derived macrophages; (B) cell alterations observed in turbot-derived macrophages infected with TRV for $8 \mathrm{~h}$

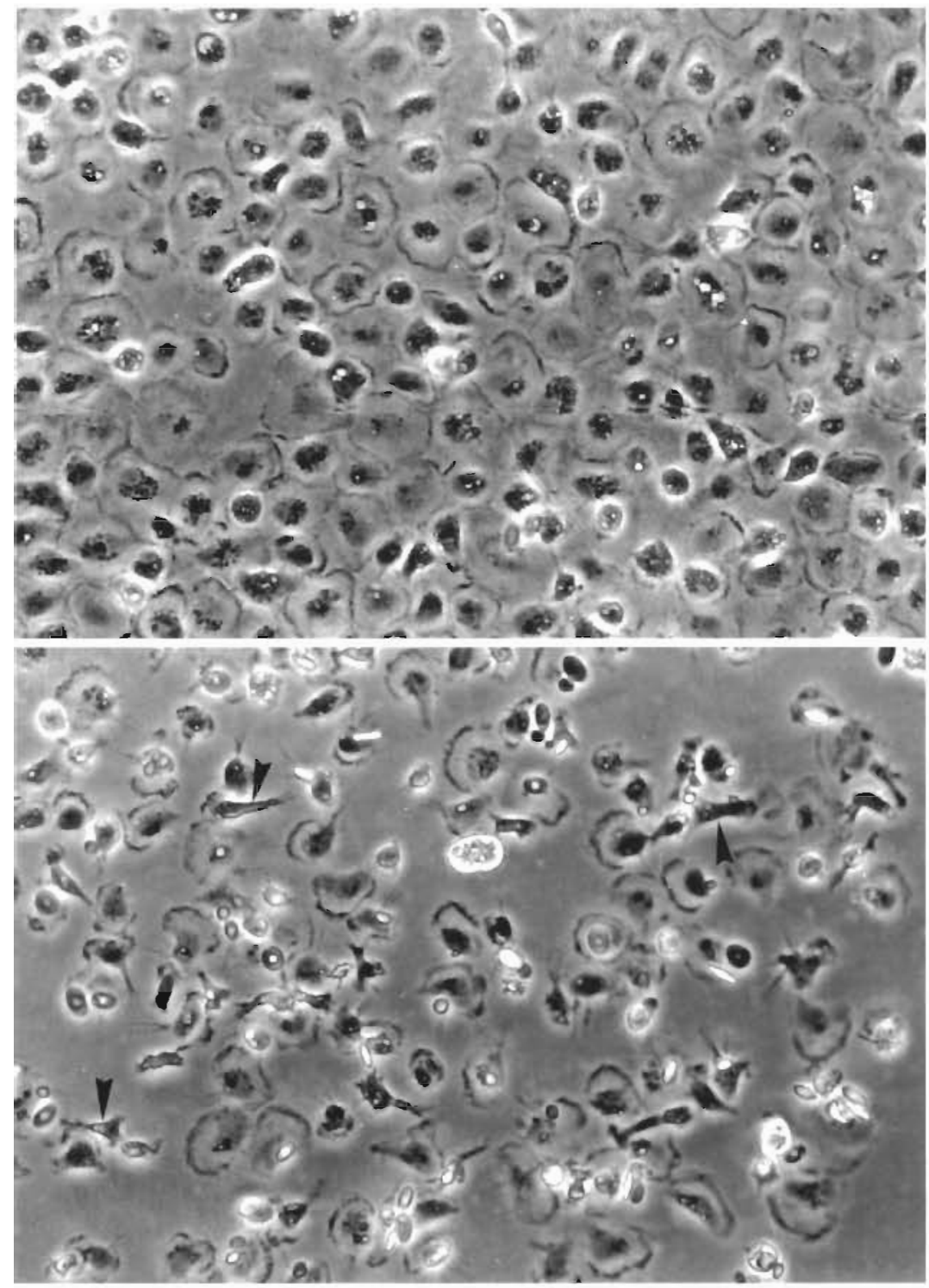



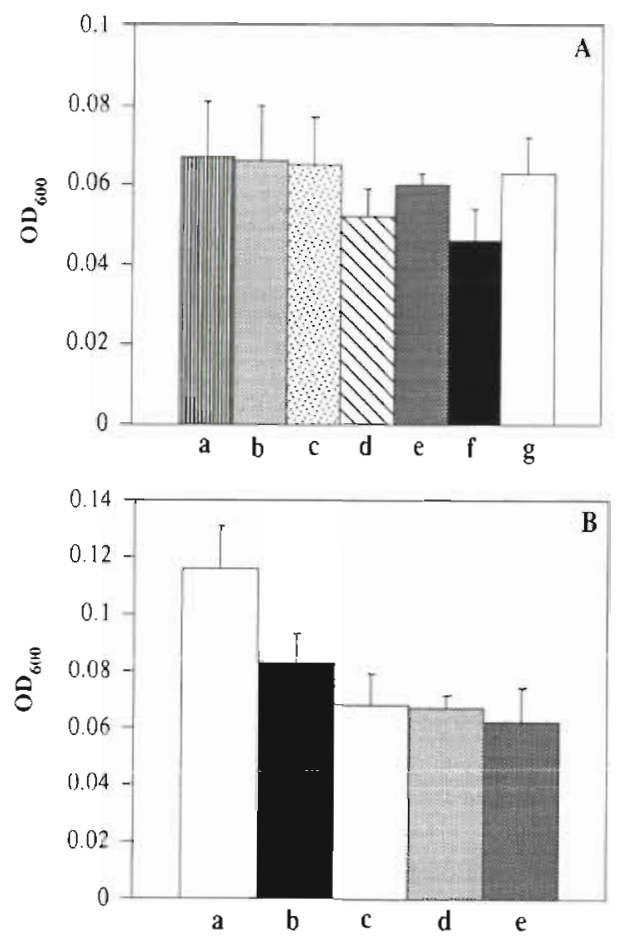

Fig. 4. Superoxide anion production by turbot macrophages. (A) Superoxide anion production, in the presence of PMA, by turbot macrophages infected with TRV for: (a) 5 min;

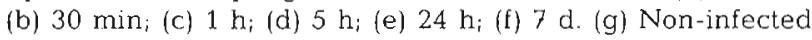
macrophages. (B) Superoxide anion production, in the presence of PMA, by turbot macrophages infected with Aeromonas salmonicida for $30 \mathrm{~min}$ and previously incubated with

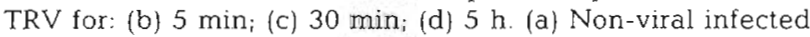
macrophages. (e) Non-bacterial or -viral infected macrophages

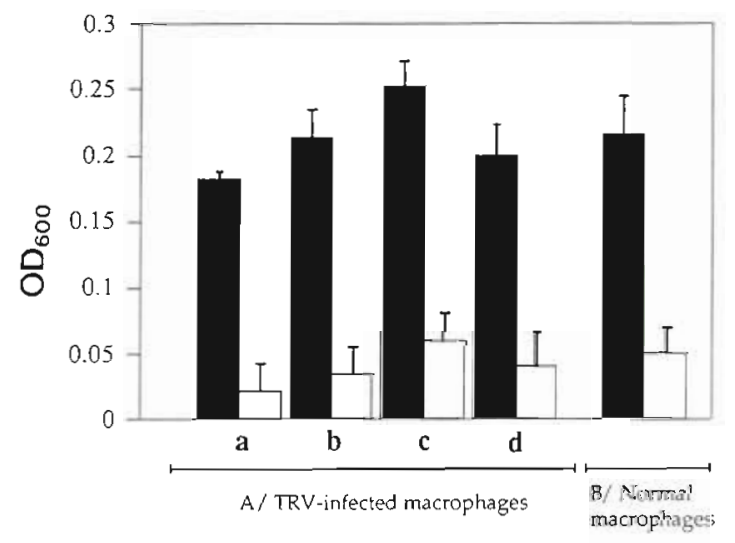

Fig. 5. Effect of TRV infection on the bactericidal activity of turbot macrophages against Aeromonas salmonicida. (A) Macrophage monolayers in 96-well plates were incubated with TRV $\left(10^{5} \mathrm{TCID}_{50}\right.$ well $\left.^{-1}\right)$ for: (a) $5 \mathrm{~min}$ (b) $30 \mathrm{~min}_{\text {; }}$ (c) $4 \mathrm{~h}_{\text {; }}$ or (d) $24 \mathrm{~h}$. Half of the wells were then employed for the 'zero time bactericidal determination' (black bars), and the remaining wells used to determine the effect of TRV infection on the bactericidal activity of macrophagges (open bars). (B) Macrophages not infected with virus were used as controls. Results are given as bacterial growth after incubation at $18^{\circ} \mathrm{C}$ overnight, as determined by optical density readings at $600 \mathrm{~nm}$ observed compared with the 'zero time bactericidal determination' in all cases.

\section{DISCUSSION}

Since the isolation of the turbot aquareovirus TRV (Lupiani et al. 1989) we have focused on the characterization of this virus under a wide range of circumstances. One topic studied was the route of entry of the viral agent into the host and its dissemination throughout the fish organs and tissues. In the course of such studies it has been surprising to observe the rapid spreading of the virus within the organism (Rivas et al. in press). The hypothesis first considered was that the virus could be transported by the blood, but the virus was not detected either in sera or in erythrocytes obtained from naturally or experimentally infected iurbot. However, the possibility that other kinds of blood cells could be involved in the rapid spreading of this virus could not be ruled out. In the present work the presence of TRV inside monocytes/macrophages of both naturally and experimentally infected fish has been demonstrated, and the role of fish macrophages in the maintenance of the virus inside the host, as well as the effect of the virus on these cells, has been studied. To our knowledge this study represents the first report in which the ability of an aquareovirus to resist killing by macrophages as well as the effect of the viral agent on the phagocytic cells has been assessed.

One of the most hostile environments encountered by an invading microorganism is the intracellular environment of macrophages, because to survive within them a pathogen must be resistant to several antimicrobial factors. Therefore, the ability of microorganisms to survive within phagocytic cells is a potent method of preventing clearance from the host. This association has been reported to exist between phagocytic cells and viruses from both fish and mammals (Yu et al. 1982, Burstin et al. 1983, Panuska et al. 1990).

Viroplasms are structures typically associated with reovirus replication. We have demonstrated by electron microscopy the presence of viroplasms containing subviral particles, as well as viral structures of different sizes scattered throughout the cytoplasm of TRVinfected macrophages, which suggests that the virus is replicating within these cells. Moreover, the results of the growth curve not only confirmed the intracellular location of TRV but also demonstrated the replication of the virus within the phagocytic cells. In addition, the capacity of TRV to infect fish macrophages treated with cytochalasin-D indicates that the virus can enter into the macrophages without being phagocytized.

On the other hand, the appearance of an undefined cytopathic effect, as well as no destruction of the 
monolayer, is in concordance with the results obtained by McChesney \& Oldstone (1987), who indicated that viruses replicating in lymphocytes are not lytic, and cytopathic effects are not often seen. Furthermore, it has been reported that the lymphocytic choriomeningitis virus infects mononuclear phagocytes and lymphocytes in vivo during both acute and persistent infection, but the virus does not kill these cells (McChesney \& Oldstone 1987). Similarly, the respiratory syncytial virus infecting alveolar macrophages does not produce cytolysis, loss of cell viability or syncytia up to 25 d p.i. (Panuska et al. 1990).

The production of microbicidal oxygen radicals by phagocytic cells is regulated by the process of activation in vivo, or by what is known as priming in vitro Activated or primed monocytes produce large amounts of oxygen radicals when they phagocytize microbes, or are triggered by chemical stimuli like PMA. The non-activation of the respiratory burst during the course of the experiment suggests that the viral agent is not scanned by the macrophages. Similar results were obtained by others (Abramson et al. 1982, Rager-Zisman et al. 1982), who reported that the vesicular stomatitis virus and the influenza virus either did not influence the respiratory burst or reduced it. In contrast, during infection of macrophages with herpes simplex virus type 2, cells acquired an increased capacity to react with a respiratory burst after membrane triggering (Mogensen et al. 1989, Giridhar et al. 1991).

It was interesting to observe that the production of $\mathrm{O}_{2}{ }^{-}$radicals by macrophages infected with Aeromonas salmonicida was reduced significantly when the phagocytic cells had previously been incubated with TRV. This reduction was first detected $5 \mathrm{~min}$ p.i., and the OD values decreased progressively until reaching similar levels to those of non-infected macrophages. These results indicate that viral internalization and subsequent replication may interact with the mechanisms involved in the reduction of molecular oxygen into the superoxide anion radical.

The bactericidal assay performed with Aeromonas salmonicida showed that the killing ability of macrophages against this microorganism was still present after incubation with TRV. It has been previously reported that superoxide anion is a potent bactericidal agent for several A. salmonicida strains (Karczewski et al. 1991). However, our findings suggest that under these circumstances alternative mechanisms to respiratory burst activity may be involved in the killing of A. salmonicida MT004, since the $\mathrm{O}_{2}^{-}$production was clearly reduced in macrophages incubated with TRV whereas the bactericidal activity was still present.

The results obtained in the present study clearly demonstrate that TRV has the ability to enter, survive, replicate and persist inside turbot macrophages in vitro without apparently affecting them, but inhibits $\mathrm{O}_{2}$ production in the presence of Aeromonas salmonicida. These observations suggest that macrophages may be a site for viral persistence in fish and that these cells may act to transport the virus to fish organs and tissues, without being affected by the viral agent. Further studies are needed to understand the mechanisms involved in the interaction between TRV and fish macrophages in vivo, as well as the potential role that macrophages may play in the immunity of the host against aquareovirus.

Acknowledgements. This work was supported by grants MAR 89-0270 from the Comisión Interministerial de Ciencia y Tecnología (CICYT), and XUGA 8030389 from Xunta de Galicia (XUGA), Spain. C.R. and C.C. acknowledge the Ministerio de Educación y Ciencia (Spain) for research fellowships.

\section{LITERATURE CITED}

Abramson JS, Mills EL, Giebink GS, Quie PG (1982) Depression of monocyte and polymorphonuclear leukocyte oxidative metabolism and bactericidal capacity by influenza A virus. Infect Immun 35:350-355

Avtalion RR, Shahrabani R (1975) Studies on phagocytosis in fish. 1. In vitro uptake and killing of living Staphylococcus aureus by peripheral leucocytes of carp (Cyprinus carpio) Immunology 29:1181-1187

Burstin SJ, Brandriss MW, Schlesinger JJ (1983) Infection of a macrophage-like cell line, P388D1, with reovirus. J Immunol 130:2915

Giridhar G, Hayakawa H, Kucera LS, Myrvik QN (1991) Priming of rabbit alveolar macrophages for enhanced oxidative responses by herpes simplex virus type 2 infection. J Leukocyte Biol 49:442-448

Graham S, Jeffries AH, Secombes CJ (1988) A novel assay to detect macrophage bactericidal activity in fish: factors influencing the killing of Aeromonas salmonicida. J Fish Dis 11:389-396

Graham S, Secombes CJ (1988) The production of a macrophage-activating factor from rainbow trout Salmo gairdneri leucocytes. Immunology 65:293-297

Haller O (1981) Natural resistance to tumors and viruses. Springer-Verlag, Berlin

Karczewski JM, Sharp GJE, Secombes CJ (1991) Susceptibility of strains of Aeromonas salmonicida to killing by cell-free generated superoxide anion. J Fish Dis 14 367-373

Lupiani B, Dopazo CP, Ledo A, Fouz B, Barja JL, Hetrick FM, Toranzo AE (1989) New syndrome of mixed bacterial and viral etiology in cultured turbot Scophthalmus maximus $J$ Aquat Anim Health 1:197-204

MacArthur JI, Fletcher TC (1985) Phagocytosis in fish. In Manning MJ. Tatner MF (eds) Fish immunology. Academic Press, London, p 29-46

McChesney MB, Oldstone MBA (1987) Viruses perturb lymphocyte functions: selected principles characterizing virusinduced immunosuppresion. A Rev Immunol 5:279-304

Mogensen SC (1979) Role of macrophages in natural resis tance to virus-infections. Microb Rev 43:1-26 
Mogensen SC, Ellermann-Eriksen S, Sommerlund M (1989) Herpes simplex virus type 2 primes mouse macrophages for an early and genetically determined respiratory burst mediated by interferon - $\alpha \backslash \beta$. J Gen Virol 70:1371-1379

Mogensen SC, Virelizier JL (1987) The interferon-macrophage alliance. In: Gresser I (ed) Interferon 8. Academic Press, London, p 55--84

Morahan PS, Connor JR, Leary KR (1985) Viruses and the versatile macrophage. Br Med Bull 41:15-21

Olivier G, Eaton CA, Campbell N (1986) Interaction between Aeromonas salmonicida and peritoneal macrophages of brook trout (Salvelinus fontinalis). Vet Immunol Immunopathol 12:223-234

Panuska JR, Cirino N, Midulla F, Despot E, McFadden ER, Huang YT (1990) Productive infection of isolated human alveolar macrophages by respiratory syncytial virus. J Clin Invest 86:113-119

Papadimetriou JM (1965) Electron micrographic features of acute murine reovirus hepatitis. Am J Pathol 47:565-585

Papadimetriou JM (1968) The biliary tract in acute murine reovirus 3 infection: light and electron microscopic study. Am J Pathol 52:595-611

Rager-Zisman B, Kunkei MI, Tanaka Y, Bloom BR (1982) Role of macrophage oxidative metabolism in resistance to vesicular stomatitis virus infection. Infect Immunol 36:1229-1237

Reed LJ, Müench $H$ (1938) A simple method of estimating fifty percent end-points. Am J Hyg 27:493-497

Responsible Subject Editor: F. M. Hetrick, College Park, Maryland, USA
Rivas C, Bandín I, Cepeda C, Dopazo CP, Barja JL (1993) In vitro studies of the interaction of the turbot rotavirus (TRV) with fish macrophages. Abstr 6th Eur Ass Fish Pathol Meeting, Brest, France. p 30

Rivas C, Bandín I, Noya M. Cepeda C, Barja JL, Dopazo CP (1996) In vitro and in vivo replication of turbot aquareovirus in turbot tissues. Dis Aquat Org 25:217-223

Rook GAW, Steele J, Umar S, Dockrell HM (1985) A simple method for the solubilization of reduced NBT, and its use as a colorimetric assay for activation of human macrophages by $\gamma$-interferon. J Immunol Methods 82:161-167

Rubin DH, Costello T, Witzleben CL, Greene MI (1987) Transport of infectious reovirus into bile: class II major histocompatibility antigen-bearing cells determine reovirus transport. J Virol 61:3222-3226

Secombes CJ, Fletcher TC (1992) The role of phagocytes in the protective mechanisms of fish. A Rev Fish Dis 2: $53-71$

Stoddart CA, Scott FW (1989) Intrinsic resistance of feline peritoneal macrophages to coronavirus infection correlates with in vivo virulence. J Virol 63:436-440

Winton JR (1989) Picornaviruses and reoviruses of fishes. In: Ahne W, Kurstak E (eds) Viruses of lower vertebrates. Springer-Verlag, Berlin, p 217-226

Yu KKY, Macdonald RD, Moore AR (1982) Replication of infectious pancreatic necrosis virus in trout leucocytes and detection of the carrier state. J Fish Dis 5:401-410

Manuscript first received: June 7, 1995

Revised version accepted: October 2, 1995 